\title{
Biosynthesis of Chloromethane in Phellinus pomaceus
}

\author{
By DAVID B. HARPER ${ }^{1,2 * \dagger}$ AND JOHN T. G. HAMILTON ${ }^{2}$ \\ ${ }^{1}$ Department of Food and Agricultural Chemistry, The Queen's University of Belfast, \\ Newforge Lane, Belfast BT9 5PX, UK \\ ${ }^{2}$ Food and Agricultural Chemistry Research Division, Department of Agriculture for Northern \\ Ireland, Newforge Lane, Belfast BT9 5PX, UK
}

(Received 5 April 1988; revised 22 May 1988)

The effects of L- and D-methionine on production of the gaseous secondary metabolite chloromethane $\left(\mathrm{CH}_{3} \mathrm{Cl}\right)$ by the white-rot fungus $P$ hellinus pomaceus were investigated. Although D-methionine stimulated $\mathrm{CH}_{3} \mathrm{Cl}$ biosynthesis , the L-isomer either failed to affect or depressed production depending on the concentration. Nevertheless, very high levels of incorporation of label $(\sim 80 \%)$ from $\mathrm{L}-\left[\right.$ methyl $\left.-{ }^{2} \mathrm{H}_{3}\right]$ methionine into $\mathrm{CH}_{3} \mathrm{Cl}$ could be achieved demonstrating that the amino acid is a highly effective precursor of $\mathrm{CH}_{3} \mathrm{Cl}$. Experiments using labelled Dmethionine showed substantial but lower incorporation. Patterns of incorporation of label from both isomers into methyl benzoate, another important volatile fungal metabolite, were very similar to those observed with $\mathrm{CH}_{3} \mathrm{Cl}$. This behaviour is only explicable in terms of either $(a)$ the utilization of the same enzyme system requiring an identical methyl donor for methylation of both chloride and benzoate ions or $(b)$ the presence of a transmethylation system. The incorporation of label from $\mathrm{L}-\left[\mathrm{methyl}^{2} \mathrm{H}_{3}\right]$ methionine into methyl 2-furoate was similar to that of methyl benzoate implying that the same methylating system was used for esterification of both 2-furoic and benzoic acids. However, the incorporation pattern for methyl salicylate was different and suggests that methyl salicylate is probably formed by $o$-hydroxylation of methyl benzoate.

\section{INTRODUCTION}

Chloromethane $\left(\mathrm{CH}_{3} \mathrm{Cl}\right)$ is a gaseous secondary metabolite produced in high yield by many species in the Hymenochaetaceae, a widespread family of white-rot fungi (Cowan et al., 1973; Harper, 1985; Harper \& Kennedy, 1986; Harper et al., 1988). Biosynthesis of this compound occurs in the majority of species in the genera Phellinus and Inonotus, both of which are characterized by bracket-like perennial fruiting bodies found on angiosperm and gymnosperm wood in temperate and tropical regions. $\mathrm{CH}_{3} \mathrm{Cl}$ of fungal origin may provide an important contribution to the $5 \mathrm{Mt}$ per year of $\mathrm{CH}_{3} \mathrm{Cl}$ estimated to be released to the atmosphere from natural sources (Harper and Kennedy, 1986; Harper et al., 1988).

Biochemically, the enzymic incorporation of halide ion into a l-carbon compound poses some very interesting questions. Although a large number of organohalogen compounds have been isolated from natural sources the only biological route so far identified for their biosynthesis has been the haloperoxidase-catalysed incorporation of halide ion in the presence of hydrogen peroxide (Neidleman \& Geigert, 1986). Clearly, such a mechanism is not feasible if halogen is directly incorporated into a 1-carbon compound. The formation of $\mathrm{CH}_{3} \mathrm{Cl}$ if haloperoxidase were responsible must necessarily involve a 2- or more carbon intermediate which either spontaneously decomposes or is enzymically converted to $\mathrm{CH}_{3} \mathrm{Cl}$. This mechanism has been invoked to explain the formation of di- and tribromomethane by an algal bromoperoxidase

† Correspondence should be sent to the Queen's University address. 
acting on 3-oxooctanoic acid in the presence of hydrogen peroxide and bromide (Theiler et al., 1978). However, no indication of the biosynthesis of monohalogenated compounds by this route has yet been reported.

Alternatively, a novel enzyme system catalysing the direct methylation of halide ion by a methyl donor such as $S$-adenosylmethionine, $N^{5}$-methyltetrahydrofolate or methylcobalamin may be present in $\mathrm{CH}_{3} \mathrm{Cl}$-producing fungi. Investigations by White (1982) using labelled Lmethionine suggested that the amino acid could act as a source of the methyl group in $\mathrm{CH}_{3} \mathrm{Cl}$ produced by Phellinus pomaceus. Unfortunately, significant incorporation was only obtained at high concentrations of methionine (i.e. between 2.5 and $10 \mathrm{~g} \mathrm{l}^{-1}$ ) likely to disrupt the normal nitrogen and carbon metabolism of the fungus. Harper \& Kennedy (1986) found no evidence of stimulation of $\mathrm{CH}_{3} \mathrm{Cl}$ production by methionine at concentrations of 100 and $200 \mathrm{mg} \mathrm{l}^{-1}$ and concluded that the rate of synthesis of $\mathrm{CH}_{3} \mathrm{Cl}$ was not limited by the endogenous concentration of the amino acid. An apparent stimulation of $\mathrm{CH}_{3} \mathrm{Cl}$ production by folic acid was reported by White (1982), although again the concentration $(0.23 \mathrm{~mm})$ used was greatly in excess of normal physiological requirements. Harper \& Kennedy (1986), using a more accurate assay system, showed no enhancement of $\mathrm{CH}_{3} \mathrm{Cl}$ production by folic acid at concentrations between 0.023 and $230 \mu \mathrm{M}$. Thus the evidence for the involvement of $S$-adenosylmethionine or $N^{5}$-methyltetrahydrofolate as methyl donor in the biosynthesis of $\mathrm{CH}_{3} \mathrm{Cl}$ as postulated by White (1982) is equivocal. Further studies are clearly warranted to establish that methionine can act as precursor of $\mathrm{CH}_{3} \mathrm{Cl}$ under normal conditions of growth and to identify the actual methyl donor.

Methyl esters of aromatic acids are major components of the volatile fraction of $P$. pomaceus (Harper \& Kennedy, 1986). In the light of this observation and the finding that the pseudohalide ion thiocyanate can act as a powerful inhibitor of both halomethane biosynthesis and methyl benzoate formation, Harper \& Kennedy (1986) suggested that methylation of halide ion and benzoate was closely linked, perhaps even mediated by the same biochemical system. Further support for this hypothesis was provided by the results of a survey (Harper et al., 1988) which indicated that whilst ester biosynthesis occurred in $52 \%$ of $\mathrm{CH}_{3} \mathrm{Cl}$-producing species of Phellinus examined, esters were not synthesized by any Phellinus species lacking the $\mathrm{CH}_{3} \mathrm{Cl}$-biosynthesis trait. Ester biosynthesis in evolutionary terms may therefore represent the consequence of an extension of the substrate range of the methylating system involved in $\mathrm{CH}_{3} \mathrm{Cl}$ production.

In this paper we describe experiments involving media supplementation with possible precursor compounds which were designed to determine the metabolic source of the methyl group in $\mathrm{CH}_{3} \mathrm{Cl}$ and the methyl esters of aromatic acids produced by $P$. pomaceus. We measured the incorporation of $\mathrm{C}^{2} \mathrm{H}_{3}$ from $\mathrm{C}^{2} \mathrm{H}_{3}$-labelled L- and D-methionine into both $\mathrm{CH}_{3} \mathrm{Cl}$ and the methyl esters of benzoic, salicylic and 2-furoic acids at various stages of fungal growth and attempted to ascertain the metabolic relationship between the compounds.

\section{METHODS}

Organisms and maintenance media. Phellinus pomaceus (Pers.) Maire (NCWRF-FPRL 33A) was acquired from the National Collection of Wood Rotting Fungi, Princes Risborough Laboratory, Building Research Establishment, Aylesbury, Bucks., UK. The fungus was maintained on slants of $5 \%(\mathrm{w} / \mathrm{v})$ malt extract agar (Oxoid) containing chloramphenicol $\left(25 \mu \mathrm{g} \mathrm{ml}^{-1}\right)$. Cultures used for inoculation were grown at $25^{\circ} \mathrm{C}$ for 3 weeks in $2 \mathrm{ml}$ vials with loosely fitting screw caps.

Chemicals. L- $\left[\right.$ methyl $\left.{ }^{13} \mathrm{C}\right]$ Methionine $\left(99\right.$ atom $\left.\%{ }^{13} \mathrm{C}\right), \mathrm{L}-\left[\right.$ methyl $\left.-{ }^{2} \mathrm{H}_{3}\right]$ methionine $\left(99.4\right.$ atom $\left.\%{ }^{2} \mathrm{H}\right)$ and $\mathrm{D}-$ [methyl $-{ }^{2} \mathrm{H}_{3}$ ]methionine $\left(97\right.$ atom $\left.\%{ }^{2} \mathrm{H}\right)$ were obtained from MSD Isotopes, Montreal, Canada. Chloromethane, bromomethane, methyl benzoate, methyl salicylate and agarose ' 10 ' were purchased from BDH; methyl 2-furoate was obtained from Aldrich.

Methionine analysis. The methionine content of mycological peptone was estimated using an LKB model 4400 Amino Acid Analyser as described by Dirar et al. (1985).

Culture media. For investigation of the percentage conversion of chloride ion to $\mathrm{CH}_{3} \mathrm{Cl}$ when the fungus was grown in the presence of supplemental L-, D-, or DL-methionine, the basic media used was glucose/mycological peptone. The medium contained $\left(\mathrm{g}^{-1}\right)$ glucose (30), mycological peptone (5), agarose ' $10^{\prime}(10)$ and $\mathrm{NaCl}$ to give a final chloride concentration of $9.5 \mathrm{mM}$. Where required L-, D- or DL-methionine was added to the medium at 0.2 or $0.4 \mathrm{~g}^{-1}$. The $\mathrm{pH}$ was adjusted to 6.5 prior to autoclaving.

For incorporation studies the fungus was grown on a cellulose-based medium in $40 \mathrm{ml}$ screw-capped septum 
vials sealed with Teflon-lined silicone discs. Into each vial filter paper ( $3.5 \mathrm{~g}$; Whatman 40 ) was placed as sheets which were wrapped around approximately $80 \%$ of the circumference of the vial. For the preparation of cellulose/mycological peptone medium, a solution $(6 \mathrm{ml})$ of mycological peptone $\left(5 \mathrm{~g}^{-1}\right)$ was added to the filter paper in each vial. To prepare cellulose/amino acids medium, a synthetic amino acids and mineral salts medium $(6 \mathrm{ml})$ was added to the filter paper in each vial. The composition of this solution was as follows $\left(\mathrm{g} \mathrm{l}^{-1}\right): \mathrm{KH}_{2} \mathrm{PO}_{4}$ (7.0), $\mathrm{Na}_{2} \mathrm{HPO}_{4}(2 \cdot 4), \mathrm{MgSO}_{4} \cdot 7 \mathrm{H}_{2} \mathrm{O}(1 \cdot 0),\left(\mathrm{NH}_{4}\right)_{2} \mathrm{SO}_{4}(2 \cdot 5), \mathrm{Ca}\left(\mathrm{NO}_{3}\right)_{2} \cdot 4 \mathrm{H}_{2} \mathrm{O}(0 \cdot 02)$ and the L-amino acids, alanine (0.258), arginine free base $(0.223)$, aspartic acid $(0.340)$, cysteine $(0.034)$, glutamic acid $(0.607)$, glycine $(0.229)$, histidine free base $(0.091)$, isoleucine $(0.142)$, leucine $(0.302)$, lysine free base $(0.306)$, phenylalanine $(0 \cdot 306)$, proline $(0 \cdot 230)$, serine $(0 \cdot 037)$, threonine $(0 \cdot 094)$, tryptophan $(0 \cdot 036)$, tyrosine $(0 \cdot 100)$ and valine $(0 \cdot 218)$. The $\mathrm{pH}$ of the solution was adjusted to 6.5 and thiamin mononitrate $\left(1.2 \mathrm{mg} \mathrm{l}^{-1}\right)$ added together with a trace element solution $\left(10 \mathrm{ml} \mathrm{l}^{-1}\right)$ of the following composition $\left(\mathrm{mg} \mathrm{l}^{-1}\right): \mathrm{CuSO}_{4} .5 \mathrm{H}_{2} \mathrm{O}(4), \mathrm{CoSO}_{4} \cdot 7 \mathrm{H}_{2} \mathrm{O}(20)$, $\mathrm{MnSO}_{4} \cdot 4 \mathrm{H}_{2} \mathrm{O}(40), \mathrm{FeSO}_{4} .7 \mathrm{H}_{2} \mathrm{O}(40)$ and $\mathrm{ZnSO}_{4} .7 \mathrm{H}_{2} \mathrm{O}(40)$.

Depending on the experiment the basic cellulose/mycological peptone or cellulose/amino acids medium was supplemented with $\mathrm{NaCl}$ or $\mathrm{NaBr}\left(0.5 \mathrm{~g} \mathrm{l}^{-1}\right)$ and $\mathrm{L}-\left[\right.$ methyl $\left.{ }^{-13} \mathrm{C}\right]$ methionine, $\mathrm{L}-\left[\right.$ methyl-2 $\left.\mathrm{H}_{3}\right]$ methionine or $\mathrm{D}-\left[\right.$ methyl $\left.{ }^{-2} \mathrm{H}_{3}\right]$ methionine at levels of 200 or $400 \mathrm{mg} \mathrm{l}^{-1}$. Choline $\left(25 \mathrm{mg} \mathrm{l}^{-1}\right)$ and benzoic acid $\left(50 \mathrm{mg} \mathrm{l}^{-1}\right)$ were added in some experiments.

Cultural conditions. For assessment of total $\mathrm{CH}_{3} \mathrm{Cl}$ generated during the growth of the fungus, cultures were grown at $25^{\circ} \mathrm{C}$ in $250 \mathrm{ml}$ conical flasks containing $20 \mathrm{ml}$ of medium. The inoculum, which was spread uniformly over the surface of the medium, was a mycelial suspension $(1 \mathrm{ml})$ prepared by homogenizing mycelia $(60 \mathrm{mg}$ wet $\mathrm{wt})$ in sterile distilled water $(20 \mathrm{ml})$ for $30 \mathrm{~s}$ with an Ultra Turrax homogenizer. Flasks were fitted with outlets prepared as described by Harper \& Kennedy (1986) permitting a limited exchange of gases between the internal and external atmospheres.

$\mathrm{CH}_{3} \mathrm{Cl}$ assay. Samples of headspace $(2 \mathrm{ml})$ were withdrawn from culture flasks through the sampling port and injected into a Pye Unicam 104 (model 74) gas chromatograph fitted with a flame ionization detector and equipped with a glass column ( $1.5 \mathrm{~m} \times 2 \mathrm{~mm}$ i.d.) packed with Tenax GC operated at a nitrogen gas flow rate of $20 \mathrm{ml} \mathrm{min}^{-1}$. The oven temperature was programmed from 60 to $120^{\circ} \mathrm{C}$ at $24^{\circ} \mathrm{C} \mathrm{min}-1$.

Calculation of total $\mathrm{CH}_{3} \mathrm{Cl}$ generated during growth. The total $\mathrm{CH}_{3} \mathrm{Cl}$ generated by a fungal culture was calculated by means of a computer integrating program as described by Harper \& Kennedy (1986) from measurements of $\mathrm{CH}_{3} \mathrm{Cl}$ concentrations in the headspace of the flask at regular intervals during incubation and a knowledge of the half-life of $\mathrm{CH}_{3} \mathrm{Cl}$ in the flask obtained from a previous calibration procedure. Each experimental treatment of the fungus was repeated in triplicate and the mean $\mathrm{CH}_{3} \mathrm{Cl}$ yield expressed as the percentage of chloride ion originally present in the medium converted to $\mathrm{CH}_{3} \mathrm{Cl} . \mathrm{CH}_{3} \mathrm{Cl}$ yields for replicates differed by an average of $6 \%$.

Isotopic incorporation studies. Preliminary experiments involved the measurement of the degree of isotopic labelling in $\mathrm{CH}_{3} \mathrm{Cl}$ after growth of the fungus on cellulose/amino acids or cellulose/mycological peptone medium with various supplements and isotopically labelled L- or D-methionine. Vials (eight for each treatment) with filter paper substrate were inoculated with a mycelial suspension $(1 \mathrm{ml})$ prepared as described under "Cultural conditions'. The inoculum was spread as uniformly as possible over the surface of the filter paper and the screw cap of the vial replaced but tightened only sufficiently to maintain sterility and not to prevent access of air. After incubating the vial for $9 \mathrm{~d}$ at $25^{\circ} \mathrm{C}$ the caps were screwed down and incubation was continued for a further $8 \mathrm{~d}$. The culture was then frozen and stored at $-15^{\circ} \mathrm{C}$ pending measurement of the isotopic labelling of $\mathrm{CH}_{3} \mathrm{Cl}$ by gas chromatography/mass spectrometry.

Subsequent incorporation experiments required measurement of the degree of isotopic labelling not only in $\mathrm{CH}_{3} \mathrm{Cl}$ but also in methyl esters of benzoic, salicylic and furoic acids at various stages during the growth of the fungus on cellulose/mycological peptone medium with isotopically labelled L-and D-methionine in the presence and absence of benzoic acid. Vials (18 for each treatment) were inoculated as described above and the screw caps replaced loosely as in the previous experiments. After $5 \mathrm{~d}$, three vials from each treatment were tightly closed. This procedure was repeated each day up to and including day 11 . Using this protocol no appreciable $\mathrm{CH}_{3} \mathrm{Cl}$ formed biologically was lost; previous experiments had demonstrated no significant synthesis of $\mathrm{CH}_{3} \mathrm{Cl}$ before day 11 in the system. After closure each set of vials was incubated for a further $7 \mathrm{~d}$ at $25^{\circ} \mathrm{C}$ and then frozen at $-15^{\circ} \mathrm{C}$ pending measurement of isotopic ratios.

Determination of ${ }^{13} \mathrm{C}$ and ${ }^{2} \mathrm{H}$ incorporation. For measurement of isotopic ratios in $\mathrm{CH}_{3} \mathrm{Cl}$ and $\mathrm{CH}_{3} \mathrm{Br}$ the following procedure was adopted. The vial containing the fungal culture was attached to a Hewlett Packard 7675A Purge and Trap sampler and purged at $25^{\circ} \mathrm{C}$ with helium at a flow rate of $20 \mathrm{ml} \mathrm{min}{ }^{-1}$ for between $30 \mathrm{~s}$ and $2 \mathrm{~min}$ depending on the concentration of halomethane in the sample. The volatile components were adsorbed on a Tenax trap. The Purge and Trap sampler was linked to a Carlo Erba Mega Series gas chromatograph equipped with a fused silica WCOT capillary column $(10 \mathrm{~m} \times 0.32 \mathrm{~mm} \mathrm{i.d.)}$ coated with Poraplot $\mathrm{Q}$ porous polymer. The entrapped volatiles were thermally desorbed using a split ratio of $10: 1$ on to the first $10 \mathrm{~cm}$ of the capillary column by cooling the latter in liquid $\mathrm{N}_{2}$. On complete desorbtion of the volatiles the oven was programmed from 30 to $150{ }^{\circ} \mathrm{C}$ at $10^{\circ} \mathrm{C} \mathrm{min}^{-1}$ with helium as carrier gas at a flow rate of $2 \mathrm{ml} \mathrm{min}{ }^{-1}$. The gas chromatograph was linked 
via a direct inlet to a Kratos MS25 RFA mass spectrometer coupled to a Data General DG30 data system. The mass spectrometer was operated in the electron impact mode at an ionizing voltage of $4 \mathrm{kV}$. The total ion current between $m / e$

The relative isotopic abundance of ${ }^{13} \mathrm{C}$ in atom $\%$ in $\mathrm{CH}_{3} \mathrm{Cl}$ was determined as the ratio of ion currents

$\frac{m / e 53}{m / e 52+m / e 53} \times 100$ at the normal retention time of $\mathrm{CH}_{3} \mathrm{Cl}$. The percentage ${ }^{13} \mathrm{C}$ incorporation was calculated from this value by subtraction of the natural ${ }^{13} \mathrm{C}$ abundance in $\mathrm{CH}_{3} \mathrm{Cl}$. The relative abundance of ${ }^{13} \mathrm{C}$ in atom \% in $\mathrm{CH}_{3} \mathrm{Br}$ was determined as the ratio of ion currents $\frac{m / e 97}{m / e 96+m / e 97} \times 100$ at the normal retention time of $\mathrm{CH}_{3} \mathrm{Br}$. The percentage ${ }^{13} \mathrm{C}$ incorporation was calculated as before, after correction for the natural ${ }^{13} \mathrm{C}$ abundance in $\mathrm{CH}_{3} \mathrm{Br}$. The percentage incorporation of $\mathrm{C}^{2} \mathrm{H}_{3}$ into $\mathrm{CH}_{3} \mathrm{Cl}$ was measured as the ratio of ion currents $\frac{m / e 55}{m / e 52+m / e 55} \times 100$ at the normal retention time of $\mathrm{CH}_{3} \mathrm{Cl}$.

For the measurement of isotopic ratios in methyl esters of benzoic, salicylic and 2-furoic acids the following procedure was used. After determination of halomethane isotopic ratios the vial was attached to the Purge and Trap sampler and purged at $80^{\circ} \mathrm{C}$ with helium at a flow rate of $20 \mathrm{ml} \mathrm{min}^{-1}$ for between 2 and $8 \mathrm{~min}$ depending on the concentration of esters in the sample. The trapped volatiles were desorbed as described above on to a fused silica WCOT capillary column $(25 \mathrm{~m} \times 0.32 \mathrm{~mm}$ i.d.) with BP10 as bonded phase. On complete desorbtion the chromatograph oven was programmed from 30 to $250^{\circ} \mathrm{C}$ at $10^{\circ} \mathrm{C} \mathrm{min}-1$ with helium as carrier gas at a flow rate of $2 \mathrm{ml} \mathrm{min}-1$. The mass spectrometer was operated as described above except that the total ion current between $m / e$ 30 and 300 was recorded. The percentage incorporation of $\mathrm{C}^{2} \mathrm{H}_{3}$ into methyl benzoate was determined as the ratio of ion currents $\frac{m / e 139}{m / e 136+m / e 139} \times 100$ at the normal retention time of methyl benzoate. Similarly the percentage incorporation of $\mathrm{C}^{2} \mathrm{H}_{3}$ into methyl 2-furoate and methyl salicylate was determined as the ratio of ion currents $\frac{m / e 155}{m / e 152+m / e 155} \times 100$ and $\frac{m / e 129}{m / e 126+m / e 129} \times 100$ respectively at the expected retention times of the compounds.

\section{RESULTS AND DISCUSSION}

\section{Comparison of effect of $\mathrm{L}-$ and $\mathrm{D}-$ methionine on $\mathrm{CH}_{3} \mathrm{Cl}$ production}

Harper \& Kennedy (1986) failed to show any significant effect of L-methionine supplementation of the medium at 100 and $200 \mathrm{mg} \mathrm{l}^{-1}$ on overall $\mathrm{CH}_{3} \mathrm{Cl}$ production by $P$. pomaceus leading them to conclude that if methionine was a precursor of $\mathrm{CH}_{3} \mathrm{Cl}$, biosynthesis of the latter was not limited by the endogenous concentration of the amino acid. An alternative explanation may be that the exogenous methionine is not taken up when the fungus is growing on a readily utilizable carbon source such as glucose. This would also explain the failure of White (1982) to obtain appreciable labelling in $\mathrm{CH}_{3} \mathrm{Cl}$ produced by the fungus when grown on malt extract medium in the presence of labelled L-methionine at a concentration of $400 \mathrm{mg} \mathrm{l}^{-1}$.

Data presented in Table 1 confirm the lack of effect of methionine $\left(200 \mathrm{mg} \mathrm{l}^{-1}\right)$ supplementation on $\mathrm{CH}_{3} \mathrm{Cl}$ biosynthesis and demonstrate a marked suppression of $\mathrm{CH}_{3} \mathrm{Cl}$ production when the concentration was increased to $400 \mathrm{mg} \mathrm{l}^{-1}$. Such inhibition may simply reflect a more general inhibition of fungal growth noted at this level of supplementation. However, D-methionine gave a significant stimulation of $\mathrm{CH}_{3} \mathrm{Cl}$ biosynthesis at a concentration of $200 \mathrm{mg} \mathrm{l}^{-1}$ and the stimulation was also apparent albeit to a lesser extent when the racemic compound was added. Whether this promotion of $\mathrm{CH}_{3} \mathrm{Cl}$ production by the D-isomer indicates that it can act per se as a precursor of $\mathrm{CH}_{3} \mathrm{Cl}$ or is affecting fungal metabolism in such a way as to enhance the availability of $\mathrm{L}$-methionine for $\mathrm{CH}_{3} \mathrm{Cl}$ biosynthesis in the fungal cell is not clear. Indeed, the increased $\mathrm{CH}_{3} \mathrm{Cl}$ production induced by the presence of the stereoisomer may result from other more general effects on secondary metabolism.

\section{Incorporation of isotopically labelled methionine into $\mathrm{CH}_{3} \mathrm{Cl}$}

In preliminary experiments $P$. pomaceus was grown in vials for $17 \mathrm{~d}$ on cellulose-based medium in the presence of ${ }^{13} \mathrm{CH}_{3}$ - and $\mathrm{C}^{2} \mathrm{H}_{3}$-labelled methionine with various media supplements and the proportion of label incorporated into $\mathrm{CH}_{3} \mathrm{Cl}$ was determined. In the 
Table 1. Effect of $\mathrm{L}$ - and D-methionine supplementation of medium on $\mathrm{CH}_{3} \mathrm{Cl}$ yields in $P$. pomaceus

$\begin{gathered}\text { Supplement to } \\ \text { glucose/mycological } \\ \text { peptone medium }\end{gathered}$
None
L-Methionine
D-Methionine

Level of supplementation $\left(\mathrm{mg} \mathrm{1}^{-1}\right)$

Percentage chloride glucose/mycological converted to $\mathrm{CH}_{3} \mathrm{Cl}$

DL-Methionine

$\begin{array}{cc}- & 59 \\ 200 & 64 \\ 400 & 37 \\ 200 & 72 \\ 400 & 65 \\ 200 & 68 \\ 400 & 69\end{array}$

Table 2. Incorporation of isotopically labelled $\mathrm{L}-$ and $\mathrm{D}-$-methionine into $\mathrm{CH}_{3} \mathrm{Cl}_{\text {or }} \mathrm{CH}_{3} \mathrm{Br}$ by $P$. pomaceus after $17 d$ growth on various media

\begin{tabular}{|c|c|c|c|}
\hline $\begin{array}{l}\text { Supplements } \\
\text { to medium }\end{array}$ & $\begin{array}{l}\text { Level of } \\
\text { supplementation } \\
\left(\mathrm{mg} \mathrm{l}^{-1}\right)\end{array}$ & $\begin{array}{l}\text { Basic } \\
\text { medium }\end{array}$ & $\begin{array}{l}\text { Percentage } \\
\text { incorporation } \\
\text { of label* }\end{array}$ \\
\hline $\begin{array}{l}\mathrm{L}-\left[\text { methyl }{ }^{13} \mathrm{C}\right] \text { Methionine } \\
\mathrm{NaCl}\end{array}$ & $\begin{array}{l}400 \\
500\end{array}$ & $\begin{array}{l}\text { Cellulose/ } \\
\text { amino acids }\end{array}$ & $27 \cdot 0 \pm 4 \cdot 6$ \\
\hline $\begin{array}{l}\mathrm{L}-\left[\text { methyl }-^{-13} \mathrm{C}\right] \text { Methionine } \\
\mathrm{NaCl}\end{array}$ & $\begin{array}{l}400 \\
500\end{array}$ & $\begin{array}{l}\text { Cellulose/ } \\
\text { mycological } \\
\text { peptone }\end{array}$ & $24 \cdot 6 \pm 3.5$ \\
\hline $\begin{array}{l}\mathrm{L}-\left[\text { methyl }-^{13} \mathrm{C}\right] \text { Methionine } \\
\mathrm{NaBr}\end{array}$ & $\begin{array}{l}400 \\
500\end{array}$ & $\begin{array}{l}\text { Cellulose/ } \\
\text { amino acids }\end{array}$ & $28.6 \pm 3.9$ \\
\hline $\begin{array}{l}\mathrm{L}-\left[\text { methyl } \mathrm{l}^{-13} \mathrm{C}\right] \text { Methionine } \\
\text { Choline } \\
\mathrm{NaCl}\end{array}$ & $\begin{array}{r}400 \\
25 \\
500\end{array}$ & $\begin{array}{l}\text { Cellulose/ } \\
\text { amino acids }\end{array}$ & $26 \cdot 5 \pm 6 \cdot 1$ \\
\hline $\begin{array}{l}\mathrm{D}-\left[\text { methyl }^{-2} \mathrm{H}_{3}\right] \text { Methionine } \\
\mathrm{NaCl}\end{array}$ & $\begin{array}{l}400 \\
500\end{array}$ & $\begin{array}{l}\text { Cellulose/ } \\
\text { amino acids }\end{array}$ & $21 \cdot 1 \pm 5 \cdot 9$ \\
\hline
\end{tabular}

presence of $400 \mathrm{mg} \mathrm{L}-[$ methyl-13 $\mathrm{C}]$ methionine $1^{-1}, 27 \%$ incorporation of ${ }^{13} \mathrm{C}$ into $\mathrm{CH}_{3} \mathrm{Cl}$ was recorded on the defined cellulose/amino acids medium. The substantial incorporation demonstrates that L-methionine can act as a precursor of $\mathrm{CH}_{3} \mathrm{Cl}$. at relatively low levels of methionine addition and contrasts with a mere $3.4 \%$ incorporation observed by White (1982). The discrepancy can probably be ascribed, as postulated above, to the inhibition of exogenous methionine uptake in the latter study during growth on a readily utilizable carbon source (maltose) present in the malt-based medium used by White.

When the defined amino acid component of the cellulose/amino acids medium was replaced by mycological peptone very little decrease in incorporation of label was observed (Table 2) despite the fact that the mycological peptone supplement contained appreciable quantities of Lmethionine ( $85 \mathrm{mg} \mathrm{l}^{-1}$ ) which might have been expected to dilute the added labelled methionine resulting in an underestimate of the percentage incorporation of label into $\mathrm{CH}_{3} \mathrm{Cl}$. However, nearly all methionine in mycological peptone was found to be in a bound form, presumably as peptides and not immediately available for fungal uptake. Only $5 \mathrm{mg}$ free methionine $\mathrm{l}^{-1}$ in the culture medium was derived from mycological peptone. This observation explains the negligible effect of substituting cellulose/mycological peptone for cellulose/amino acids medium on the level of incorporation and allowed the former medium to be used in the subsequent more detailed isotope incoporation experiments described in the next section.

When $\mathrm{NaCl}$ in the medium was replaced by $\mathrm{NaBr}$ incorporation of label into $\mathrm{CH}_{3} \mathrm{Br}$ exhibited no significant difference from that into $\mathrm{CH}_{3} \mathrm{Cl}$ confirming that, as anticipated, both 
halomethanes are almost certainly derived by the action of the same enzyme from the same precursor pool. The finding also establishes that the observed preference of the fungal methylating system for bromide over chloride (Harper \& Kennedy, 1986) does not significantly affect the rate of turnover in the pool of methyl donor. The addition of unlabelled choline to the culture medium did not alter the incorporation of ${ }^{13} \mathrm{CH}_{3}$ from $\mathrm{L}-\left[\right.$ methyl $\left.-{ }^{13} \mathrm{C}\right]$ methionine into $\mathrm{CH}_{3} \mathrm{Cl}$ to any significant extent (Table 2) thereby appearing to eliminate any intermediary role for this compound in the biosynthesis of halomethane.

Interestingly, in view of the stimulatory effect of D-methionine on $\mathrm{CH}_{3} \mathrm{Cl}$ production, addition of $\mathrm{D}-\left[\right.$ methyl $\left.-{ }^{2} \mathrm{H}_{3}\right]$ methionine to the growth medium led to a substantial incorporation of $\mathrm{C}^{2} \mathrm{H}_{3}$ into $\mathrm{CH}_{3} \mathrm{Cl}$ (Table 2), implying that either the $\mathrm{CH}_{3} \mathrm{Cl}$ generating system was almost equally active on methyl donors derived from both isomers of methionine or that rapid enzymic racemization occurred within the fungal cell.

\section{Comparison of incorporation of $\mathrm{L}-$ and $\mathrm{D}-\left[\right.$ methyl $\left.{ }^{2} \mathrm{H}_{3}\right]$ methionine into $\mathrm{CH}_{3} \mathrm{Cl}$ and methyl benzoate}

In order to examine the relationship between the biosynthesis of methyl benzoate and that of $\mathrm{CH}_{3} \mathrm{Cl}$ the levels of incorporation into the two compounds from both isomers of labelled methionine after various periods of fungal growth were measured. The isotopic compositions of $\mathrm{CH}_{3} \mathrm{Cl}$ and methyl benzoate produced by the fungus in sealed vials were determined from the point at which $\mathrm{CH}_{3} \mathrm{Cl}$ was first present in the headspace of the vial in detectable quantities (Fig. $1)$. Very high $(\sim 80 \%)$ and almost identical levels of incorporation of the methyl group from $L$ methionine into both $\mathrm{CH}_{3} \mathrm{Cl}$ and methyl benzoate were observed initially. From the 14th day of growth the levels began to fall, though at very similar rates, as the highly labelled $\mathrm{CH}_{3} \mathrm{Cl}$ and methyl benzoate formed in the early stages of growth were diluted by the unlabelled compounds formed from endogenously synthesized L-methionine whilst at the same time the exogenous labelled methionine was depleted. By day 17 the labelling in $\mathrm{CH}_{3} \mathrm{Cl}$ was not substantially different from that found in the preliminary experiments.

When the fungus was grown in the presence of labelled D-methionine, incorporation $(\sim 20 \%)$ into $\mathrm{CH}_{3} \mathrm{Cl}$ and methyl benzoate was very much lower than that observed in the presence of $\mathrm{L}$ methionine. However, the level subsequently increased to a maximun of over $50 \%$ on the 14 th day of growth but declined thereafter at a rate very similar to that found with the $L$-isomer. The reason for this unusual incorporation pattern is not immediately apparent but can be explained in terms of the suggestions made above. If the $\mathrm{CH}_{3} \mathrm{Cl}$ generating system can only use $\mathrm{L}$ methionine as source of the methyl donor then the initial increase in incorporation may represent the induction of a racemase for the amino acid. Alternatively if the $\mathrm{CH}_{3} \mathrm{Cl}$ generating system can utilize both L- or D-methionine as source of the methyl donor the preliminary increase may reflect the induction of an uptake system for D-methionine. Of particular note is the remarkable correspondence between the patterns of incorporation of D-methionine into $\mathrm{CH}_{3} \mathrm{Cl}$ and methyl benzoate which did not differ from each other to a significant extent at any stage during the growth period studied (Fig. 1).

Several general conclusions regarding the origin of $\mathrm{CH}_{3} \mathrm{Cl}$ and methyl benzoate can be drawn from the results presented in Fig. 1. The exceptionally high and initially very similar incorporations of $\mathrm{C}^{2} \mathrm{H}_{3}$ from $\mathrm{L}-\left[\right.$ methyl $\left.-{ }^{2} \mathrm{H}_{3}\right]$ methionine into $\mathrm{CH}_{3} \mathrm{Cl}$ and methyl benzoate leave no doubt that L-methionine is a highly effective precursor of the methyl group in both these compounds. However, it is not possible to deduce from the results obtained with D-methionine whether the methyl group of the D-isomer or a methyl donor derived from it can be used directly for methylation of chloride or benzoate or whether the amino acid must first undergo racemization. The striking similarity of the incorporation patterns into $\mathrm{CH}_{3} \mathrm{Cl}$ and methyl benzoate when grown on both labelled L- and D-methionine can only be interpreted in terms of one of the following biochemical possibilities.

(a) The same enzyme system requiring an identical methyl donor is utilized for the methylation of both chloride and benzoate ions. The slight disparity between the incorporation patterns into the two compounds from day 14 onwards in the L-methionine experiment can be adequately explained on the basis that for a short period between days 13 and 14 the formation 


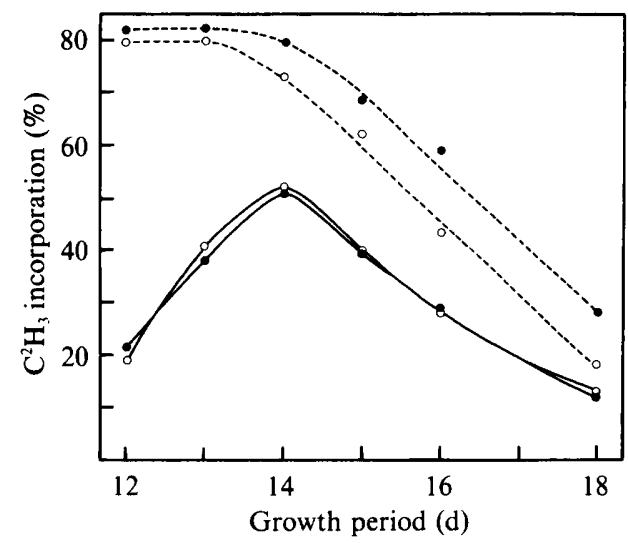

Fig. 1. Incorporation of methyl- ${ }^{2} \mathrm{H}_{3}$ from $\mathrm{L}-\left[\right.$ methyl $\left.{ }^{2} \mathrm{H}_{3}\right]$ methionine (---) and $\mathrm{D}-\left[\right.$ methyl- $\left.{ }^{2} \mathrm{H}_{3}\right]$ methionine $(-)$ into $\mathrm{CH}_{3} \mathrm{Cl}(\mathrm{O})$ and methyl benzoate $(\mathcal{O})$ by $\boldsymbol{P}$. pomaceus. The fungus was grown on cellulose/mycological peptone medium supplemented with $\mathrm{NaCl}\left(0.5 \mathrm{~g}^{-1}\right)$ and labelled L- or D-methionine $\left(0 \cdot 4 \mathrm{~g} \mathrm{l}^{-1}\right)$.

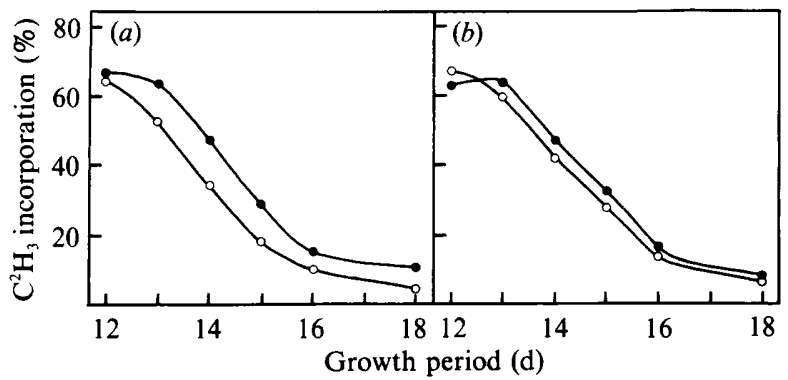

Fig. 2. Incorporation of methyl- ${ }^{2} \mathrm{H}_{3}$ from $\mathrm{L}-\left[\right.$ methyl $\left.-{ }^{2} \mathrm{H}_{3}\right]$ methionine into $\mathrm{CH}_{3} \mathrm{Cl}(\mathrm{O})$ and methyl benzoate ( $O$ ) by $P$. pomaceus in $(a)$ the absence and $(b)$ the presence of benzoic acid. The fungus was grown on cellulose/mycological peptone medium supplemented with $\mathrm{NaCl}\left(0.5 \mathrm{~g}^{-1}\right)$ and labelled L-methionine $\left(0.2 \mathrm{~g} \mathrm{l}^{-1}\right) \pm$ benzoic acid $\left(0.05 \mathrm{~g} \mathrm{l}^{-1}\right)$.

of methyl benzoate was limited by the endogenous concentration of benzoate whereas at no stage during growth was $\mathrm{CH}_{3} \mathrm{Cl}$ biosynthesis constrained by chloride concentration. As the concentration of benzoate is determined by the rate of biosynthesis by the fungus whereas chloride concentration is probably governed solely by the rate of uptake from the culture medium, this assumption appears feasible. In order to test this hypothesis the incorporation of L-methionine into $\mathrm{CH}_{3} \mathrm{Cl}$ and methyl benzoate was measured when the fungus was grown in the presence and absence of added benzoic acid in the culture medium (Fig. $2 a, b$ ). The patterns of incorporation into the compounds were almost identical in the presence of a relatively low concentration of exogenous benzoic acid suggesting that benzoic acid may, in the absence of an exogenous source of the compound, limit the rate of synthesis of methyl benzoate for a short period during fungal growth. It could be argued that the similarity of the incorporation patterns observed is explicable in terms of two distinct enzyme systems using the same methyl donor. However, for such a postulate to be tenable the possession of identical kinetic parameters by the two enzymes and their induction at identical points in the fungal growth cycle would have to be invoked. Such circumstances cannot be regarded as likely.

(b) Rapid transmethylation may occur between methyl benzoate and inorganic chloride as shown below in reaction 1 , or alternatively between $\mathrm{CH}_{3} \mathrm{Cl}$ and benzoic acid as in reaction 2 . An activated derivative of benzoic acid such as benzoyl-CoA rather than the acid per se might conceivably be the substrate for the enzyme in reaction 2 . 


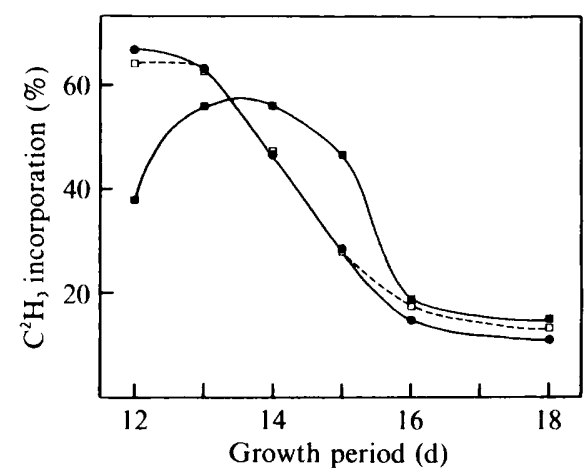

Fig. 3. Incorporation of methyl- ${ }^{2} \mathrm{H}_{3}$ from $\mathrm{L}-\left[\right.$ methyl $\left.{ }^{2} \mathrm{H}_{3}\right]$ methionine into methyl benzoate (O), methyl 2-furoate $\left(--\square^{--}\right)$and methyl salicylate $(\square)$ in $P$. pomaceus. The fungus was grown on cellulose/mycological peptone medium supplemented with $\mathrm{NaCl}\left(0.5 \mathrm{~g} \mathrm{l}^{-1}\right)$ and labelled $\mathrm{L}$-methionine $\left(0 \cdot 2 \mathrm{~g} \mathrm{l}^{-1}\right)$.

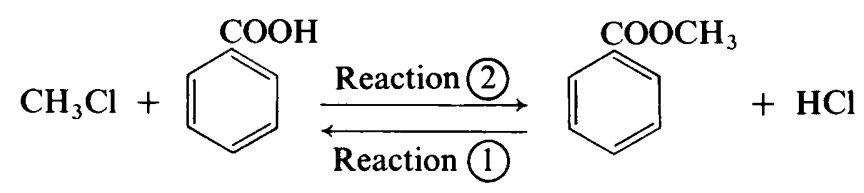

The slight delay in the progressive decline over time in the labelling of methyl benzoate as compared to $\mathrm{CH}_{3} \mathrm{Cl}$ in the L-methionine experiment illustrated in Fig. 1 would, on the basis of this hypothesis, tend to favour reaction 2 . However, a third possibility cannot be ignored in which an enzyme catalyses both the forward and reverse reactions above so that the overall direction of the reaction is dependent on the relative concentrations of the reactants.

Experiments involving the incubation of fungal mycelia with isotopically labelled $\mathrm{CH}_{3} \mathrm{Cl}$ and methyl benzoate are currently underway to distinguish between the broad specificity methylating system utilizing a common methyl donor described in $(a)$ and the transmethylation possibilities discussed in $(b)$.

\section{Incorporation of $\mathrm{L}-\left[\right.$ methyl $\left.-{ }^{2} \mathrm{H}_{3}\right]$ methionine into methyl 2-furoate and methyl salicylate}

Harper \& Kennedy (1986) noted that in addition to methyl benzoate, methyl esters of other aromatic acids such as 2-furoic and salicylic acids were major components of the volatile fraction of $P$. pomaceus. Such methyl esters were also associated with the presence of methyl benzoate in a number of other halomethane producing species of Phellinus examined by Harper et al. (1988). To determine whether all methyl esters present in such Phellinus species were formed by the same methylating system the levels of incorporation of label from L-[methyl${ }^{2} \mathrm{H}_{3}$ ]methionine into the various esters were compared (Fig. 3). The pattern of incorporation of label into methyl furoate is very similar to that recorded for methyl benzoate, suggesting that the methylation of furoic acid is probably mediated by the same enzyme system as that methylating benzoic acid. However, the pattern of incorporation into methyl salicylate is quite different from that into methyl benzoate. Initial incorporation into methyl salicylate is comparatively low. A low level of biosynthesis of the compound at this stage of growth presumably contributes little label to the unlabelled compound carried over in the inoculum. Maximum incorporation into methyl salicylate was not attained until the 14th day of growth by which time labelling of methyl benzoate and furoate was decreasing rapidly. This divergent behaviour implies that methyl salicylate is almost certainly not biosynthesized by direct methylation of the corresponding acid in the same manner as the other methyl esters. Instead the response is consistent with the formation of methyl salicylate by $o$-hydroxylation of methyl benzoate. Labelling of methyl salicylate will therefore tend to lag behind that of methyl benzoate. 


\section{REFERENCES}

Cowan, M. I., Glen, A. T., Hutchinson, S. A., MacCartney, M. E., Mackintosh, J. M. \& Moss, A. M. (1973). Production of volatile metabolites by species of Fomes. Transactions of the British Mycological Society 60, 347-356.

Dirar, H. A., HARPER, D. B. \& Collins, M. A. (1985). Biochemical and microbiological studies on kawal a meat substitute derived by fermentation of Cassia obtusifolia leaves. Journal of the Science of Food and Agriculture 36, 881-892.

HARPER, D. B. (1985). Halomethane from halide ion a highly efficient fungal conversion of environmental significance. Nature, London. 315, 55-57.

HARPER, D. B. \& KenNedy, J. T. (1986). Effect of growth conditions on halomethane production by
Phellinus species: biological and environmental implications. Journal of General Microbiology 132, 1231-1246.

HARPER, D. B., KenNedy, J. T. \& Hamilton, J. T. G. (1988). Chloromethane synthesis in poroid fungi. Phytochemistry (in the Press).

Neidleman, S. L. \& Geigert, J. (1986). Biohalogenation: Principles, Basic Roles and Applications. Chichester: Ellis Horwood.

Theiler, R., COOK, J. C., Hager, L. P. \& Siuda, J. F. (1978). Halohydrocarbon synthesis by bromoperoxidase. Science 202, 1094-1096.

WHITE, R. H. (1982). Biosynthesis of methyl chloride in the fungus, Phellinus pomaceus. Archives of Microbiology 132, 100-102. 